\title{
Improved river continuity facilitates fishes' abilities to track future environmental changes
}

Johannes Radinger (1) https://orcid.org/0000-0002-2637-9464 , Franz Hölker (1) https://orcid.org/0000-0001-5932-266X ,

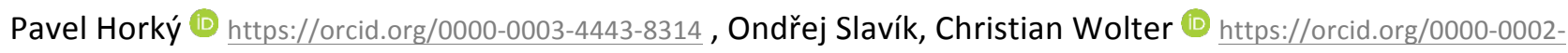
2819-2900

DOI

10.1016/j.jenvman.2017.12.011

Original publication date

18 December 2017 (Available online)

Document version

Accepted manuscript

Published in

Journal of Environmental Management

\section{Citation (Vancouver)}

Radinger J, Hölker F, Horky P, Slavik O, Wolter C. Improved river continuity facilitates fishes' abilities to track future environmental changes. Journal of Environmental Management. 2018;208:169-79. 


\title{
Improved river continuity facilitates fishes' abilities to track future environmental changes
}

\author{
Johannes Radinger ${ }^{1,2^{*}}$, Franz Hölker ${ }^{1}$, \\ Pavel Horký ${ }^{3}$, Ondřej Slavík ${ }^{3}$, Christian Wolter ${ }^{1}$ \\ ${ }^{1}$ Leibniz-Institute of Freshwater Ecology and Inland Fisheries \\ Müggelseedamm 310, 12587 Berlin, Germany \\ ${ }^{2}$ GRECO, Institute of Aquatic Ecology, University of Girona, \\ Girona, Spain \\ ${ }^{3}$ Czech University of Life Sciences Prague, Department of Zoology and Fisheries \\ 16521 Praha 6 - Suchdol, Czech Republic \\ *corresponding author: johannes.radinger@udg.edu
}




\begin{abstract}
Barriers represent one of the largest anthropogenic impacts on the ecological status of rivers, and they also potentially restrict fishes' ability to respond to future environmental changes. Thus, river management aims to restore the longitudinal connectivity of rivers to allow continuous migration and movement of water, sediments and biota. However, it is often unclear whether the targeted barriers are also those most relevant for fish species, particularly to track future habitat shifts caused by environmental change.

In this study, we applied species distribution models and the GIS-based fish dispersal model FIDIMO to evaluate the impacts of barriers (e.g. weirs and dams) on the dispersal of 17 native fish species in the European River Elbe with a particular focus on climate- and land useinduced habitat shifts. Specifically, we compared three scenarios of longitudinal connectivity: (i) current longitudinal connectivity, (ii) connectivity improvements as planned by river managers for 2021 and (iii) a reference with full longitudinal connectivity.

The models indicated that barriers restricted the movement of two modeled fish species on average, thus impeding fishes' abilities to track future habitat shifts. Moreover, the impact of barriers e.g. on the number of species affected increased downstream. For the River Elbe, our results suggest that river management has most likely identified the most relevant barriers in respect to the modeled species and future environmental change. We emphasize that river management and barrier prioritization must thoroughly consider species-specific movement and dispersal abilities, as well as the specific spatial arrangement of barriers in the river system in relation to the spatial distribution of species' populations and suitable habitats.

Keywords: Barrier prioritization; Climate change; Habitat shift; Longitudinal Connectivity; River Basin Management; River Elbe;
\end{abstract}




\section{Introduction}

Barriers represent one of the largest anthropogenic impacts on river ecosystems, affecting species' habitats and habitat connectivity on multiple spatial and temporal scales (Fuller et al., 2015). These impacts include (i) hydrological modifications and changes to the flow and sediment regime with associated changes to riverine habitats (e.g. Graf, 2006; Ligon et al., 1995; Petts and Gurnell, 2005), (ii) the general loss of connectivity of river habitats (e.g. Cote et al., 2009), (iii) in particular the impediment of ontogenetic migrations (e.g. spawning runs) and ordinary habitat movements of river fish (e.g. Marschall et al., 2011; Radinger and Wolter, 2015), and (iv) associated genetic fragmentation of populations (e.g. Gouskov et al., 2016). Thus, to improve the ecological status of river ecosystems, river management commonly aims to restore and improve longitudinal connectivity to allow continuous migration and movement of water, sediments and biota. Correspondingly, the continuity of rivers constitutes an indispensable element for the assessment of river water bodies according to the European water framework directive (EU-WFD) (Reyjol et al., 2014). In fact, to be classified as high status, the continuity of rivers must not be "disturbed by anthropogenic activities and allow[] undisturbed migration of aquatic organisms and sediment transport" (European Parliament and Council of the European Union, 2000).

At a global scale, climate and land use change constitute anthropogenic pressures on freshwater ecosystems (Meyer et al., 1999; Woodward et al., 2010), and these are superimposed on the local and regional impacts of habitat degradation and barriers to movement (Kail et al., 2015). These large-scale environmental pressures and their interacting effects will change the diversity and composition of river fish communities in entire catchments via modification to their habitats (e.g. Radinger et al., 2016). In particular, climate and land use changes cause 
species' habitats to move in space associated with spatially distributed losses and gains of suitable habitats. If and how species can track future habitat shifts largely depends on the extent of these shifts, the species-specific dispersal ability and on barriers to movement that impede species from reaching newly available habitats (Radinger et al., 2017). Hence, barriers and the associated loss of river continuity constitute not only an impact for the current ecological status of river systems, but might also restrict fishes' ability to respond to future climate and land use changes (Gibson-Reinemer et al., 2017).

The increasing awareness of the ecological impacts of barriers has led to the development of management tools to prioritize dams and identify those mostly affecting network connectivity (Brevé et al., 2014; Kemp and O'Hanley, 2010; O’Hanley et al., 2013; Segurado et al., 2013). Recent studies emphasized that the location of a barrier within a river system and especially its location relative to suitable habitats and species occurrences determines its impact on fish (Kuemmerlen et al., 2016; Musil et al., 2012; Radinger and Wolter, 2015). As a consequence, current attempts in river management at the catchment scale typically aim for an overall improvement of river continuity by installing fish migration facilities for specific barriers or by removing barriers completely. However, it is often unclear whether these targeted barriers are also those most relevant for fish species, particularly to track future habitat shifts as caused by environmental change.

Generally, weirs and dams are the two major types of barriers in the River Elbe (Fig. 1). Weirs are barriers creating impoundments upstream, are typically of smaller size and lower height compared to dams and are often characterized by overflowing water e.g. via a spillway. Numerous weirs in the River Elbe have been built for hydropower use or as small-scale watermills. In contrast, dams are barriers typically creating large reservoirs holding back 
significant amounts of water and which commonly serve multiple purposes such as generation of hydropower, flow and flood control, irrigation or drinking water supply.
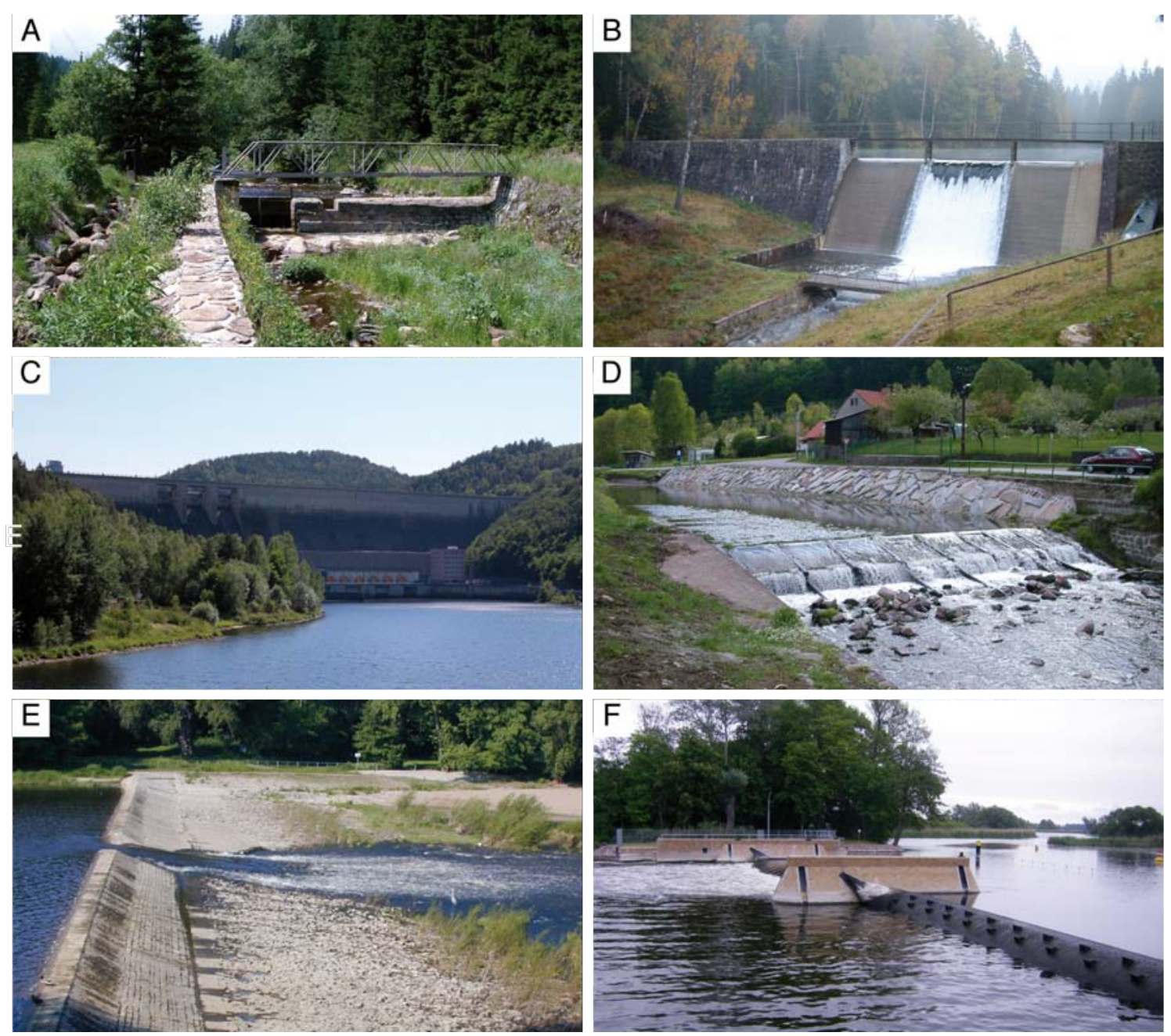

Figure 1. Examples of different types of barriers in the River Elbe network: (A) small weir Františkov in the upper River Vltava, equipped with a non-functional fish pass. (B) small dam Černé jezero in the River Úhlava, no fish pass. (C) large Orlík dam in the River Vltava, highest dam (91 m) in the Czech Republic, no fish pass. (D) weir Čenkov in the River Litavka, no fish pass. (E) weir in the river branch Alte Elbe at Magdeburg. (F) weir in the River Havel at Bahnitz, equipped with a fish pass.

This study aimed to evaluate the impacts of barriers (e.g. weirs and dams) on the 
dispersal of 17 native fish species in the European River Elbe. We applied the novel GIS-based fish dispersal model FIDIMO (Radinger et al., 2014) to (i) investigate which barriers potentially impede species-specific dispersal movements in the River Elbe and to which extent, (ii) assess the effects of planned improvements of longitudinal connectivity (i.e. barrier passability) on river fish dispersal and to (iii) assess the relevance of barriers for fish to track predicted shifts of suitable habitats between current and future climate and land use conditions. Specifically, we compared three scenarios of longitudinal connectivity in the River Elbe: (i) current longitudinal connectivity, (ii) connectivity for 2021 as planned by river managers and (iii) a reference scenario with full longitudinal connectivity.

It was hypothesized that restoring longitudinal connectivity for fish will significantly improve fish dispersal, but there might be a threshold whereupon further barrier removal will not substantially add measurable ecological improvements for fish populations. It was assumed that

river management plans have properly identified and addressed the most relevant barriers within the River Elbe system. Modeling should aid river management by informing efforts to restore longitudinal connectivity and to increase its ecological efficiency.

\section{$2 \quad$ Methods and Materials}

The applied model framework comprised three principal steps: First, we modeled and projected current and future suitable habitats (i.e. species distribution patterns) of 17 fish species in the River Elbe network. Second, we applied a fish dispersal model to assess whether and to which extent the shifts of future habitats can be tracked by species-specific dispersal abilities, while considering different scenarios of longitudinal connectivity (i.e. barriers to movement). Third, we identified those barriers in the River Elbe that constitute the greatest impact on the 
modeled fish species.

\subsection{Models of current and future fish distributions in the River Elbe}

First, we calculated so-called species distribution models (SDM), i.e. statistical relationship between habitat parameters (climate, land use, etc.) and the occurrence of a species, for 17 fishes in the European River Elbe and its tributaries (Fig. 2, $148250 \mathrm{~km}^{2}$; bounding box N: 5405'26"N, S: 48¹9'25"7N, W: 905'55"E, E: 17²6'51"E). 


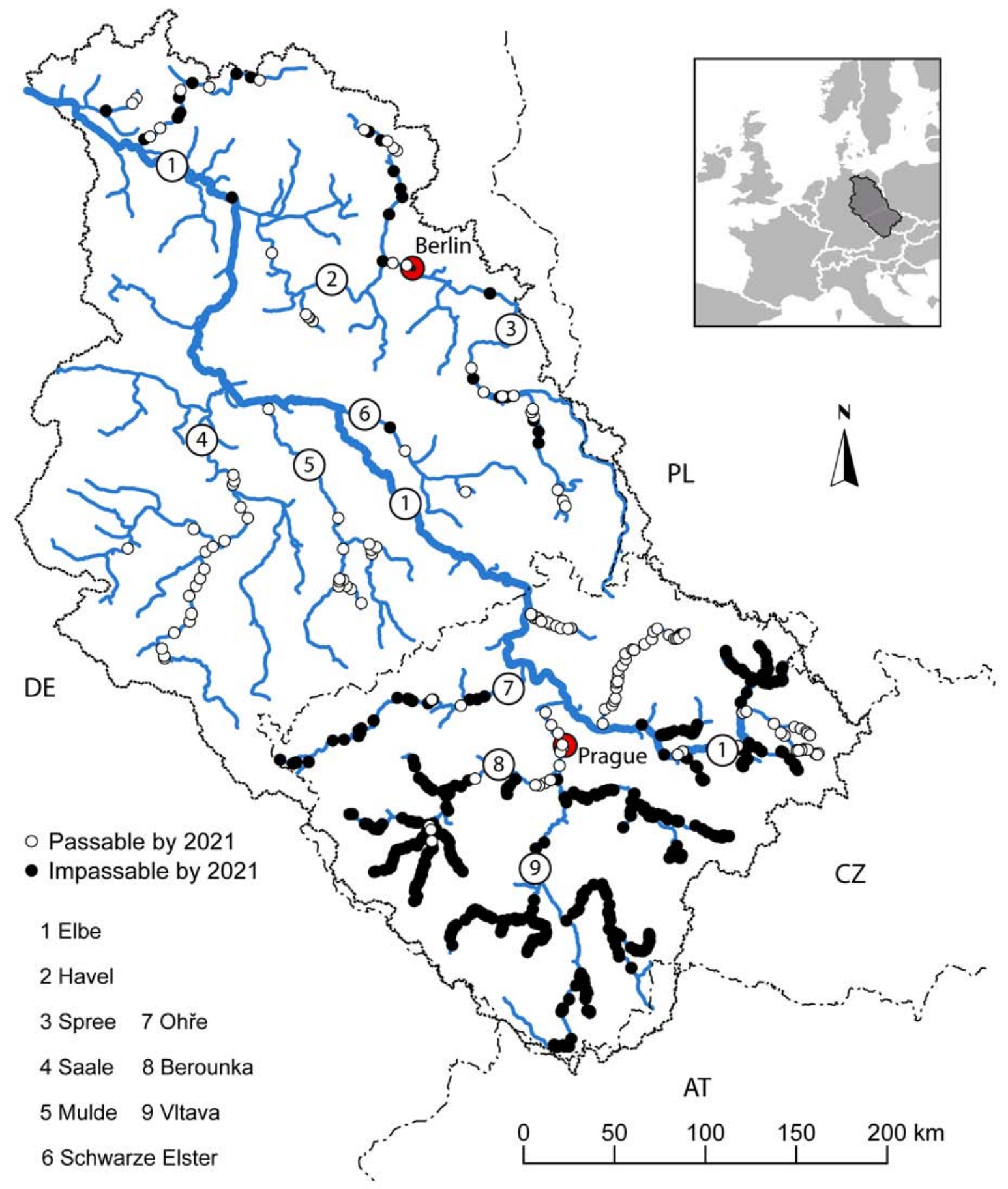

Figure 2. Overview of the River Elbe system and currently impassable barriers. Open circles refer to barriers planned to become passable by $2021(\mathrm{n}=144)$; Filled circles refer to barriers that will remain impassable after $2021(\mathrm{n}=455)$. Barriers which are already partly or fully passable $(\mathrm{n}=256)$ are not displayed. 
The fish data in the River Elbe and its major tributaries comprised of 1762 samplings collected between 1990 and 2014. Fish abundances were mostly obtained by standard monitoring electro fishing, except for the main stem of the Elbe that has been partly sampled with other methods (e.g. stow nets, drift nets and gillnets). For the analysis, the fish sampling data were transformed into presence/absence data and spatially and temporally pooled to ensure a minimum distance of $2500 \mathrm{~m}$ between the pooled sites $(\mathrm{n}=122)$. For all further analysis of barrier effects, only 17 native, non-migratory species with good average SDM model quality (area under curve, AUC $>0.8$ ) were considered (Radinger et al., 2017). The predictor variables for the current environmental conditions were (i) five stream topological variables (stream slope, stream order etc.), (ii) 19 bioclimatic variables for actual climate scenarios (IPCC5), and (iii) 12 land use variables for current conditions (CORINE) (Table S1 in the supplementary material). For each species, we built 10 boosted regression tree models (BRT, Elith and Leathwick, 2013) using 80\% of the sites for model fitting and $20 \%$ for model validation. For each BRT model replicate, we applied a stepwise selection of relevant predictor variables based on model-internal crossvalidation (Hijmans et al., 2014). The probability maps gained from the 10 model replicates were then averaged into a single consensus probability map for each species using the models' AUC quality (Area under the receiver-operator curve) as a weighing factor (Marmion et al., 2009). Each species-specific consensus probability map was transformed into a presence/absence map using a threshold that maximizes the sum of sensitivity (true positive rate) and specificity (true negative rate) (Liu et al., 2005). Further details on the SDM modelling procedure and specific model settings are provided in Radinger et al. (2016). The SDM modeling steps allowed to project the distribution patterns for each of the 17 species for the entire River Elbe catchment and 
to identify edge populations. Edge populations, i.e. the outermost cells at the limits of a species' current distribution range, are particularly relevant as starting points (source populations) for species dispersal, i.e. for tracking shifts of suitable habitats (Kühn et al., 2013).

To identify and project future suitable habitats, we applied two alternative predictor variable sets of environmental change that combine scenarios of moderate and severe future climate and land use change until 2050. For moderate and severe future climate conditions, we selected 19 bioclimatic variables (source: worldclim.org) obtained from a downscaled global circulation model (MPI-ESM LR, Max-Planck Institute Earth System Model, Giorgetta et al., 2013) for the IPCC-scenarios RCP2.6 (moderate) and RCP8.5 (severe) (Moss et al., 2010). These moderate and severe climate models project average annual temperature increases of $1.3^{\circ} \mathrm{C}(\mathrm{RCP} 2.6)$ and $2.2^{\circ} \mathrm{C}(\mathrm{RCP} 8.5)$, respectively, for the River Elbe catchment by 2050 (Radinger et al., 2017). For future land use conditions by 2050, we considered downscaled projections for a moderate scenario (“business-as-might-be-usual”, BAMBU), assuming continuation of current socio-economic and policy strategies with intermediate changes in land use, and a severe scenario ("Growth Applied Strategy", GRAS) implying economic growth with maximum changes in land use (Dendoncker et al., 2007, 2006; Spangenberg et al., 2012). For the moderate environmental change scenario, we combined moderate changes in climate (RCP2.6) with moderate changes in future land use (BAMBU). For the severe environmental change scenario, we combined severe changes in climate (RCP8.5) with severe changes in future land use (GRAS).

\subsection{Modeling fish dispersal under consideration of barriers to movement}

To assess the potential effects of barriers on the species-specific abilities of fish to 
compensate for predicted range shifts, we applied the open source GIS-based fish dispersal model FIDIMO (Radinger et al., 2014). FIDIMO calculates fish dispersal as leptokurtic diffusion from starting points (here the edge populations at the limits of a species' current distribution), described by a double-normal probability density function (i.e. dispersal kernel, Fig. 3):

$$
f(x)=p \times \frac{1}{\sqrt{2 \pi \sigma_{\text {stat }}^{2}}} \times \mathrm{e}^{-\frac{(x-\mu)^{2}}{2 \sigma_{\text {stat }}}}+(1-p) \times \frac{1}{\sqrt{2 \pi \sigma_{\text {mob }}^{2}}} \times \mathrm{e}^{-\frac{(x-\mu)^{2}}{2 \sigma_{\text {mob }}^{2}}}
$$

where $x$ is the distance from the edge-population, $\sigma_{\text {stat }}$ is the mean movement distance of the stationary component of the population, $\sigma_{\mathrm{mob}}$ is the mean movement distance of the mobile component and $p$ is the share of the stationary component of the total population. The mean movement distances of the stationary $\left(\sigma_{\mathrm{stat}}\right)$ and the mobile components $\left(\sigma_{\mathrm{mob}}\right)$ are obtained from a multiple regression model (Radinger and Wolter, 2014) for each species. The share of the stationary component $p$ was set to the commonly observed mean value of 0.67 (Radinger and Wolter, 2014). The dispersal model was calculated for each species separately in a loop of $3 \times 5$ years $=15$ model years. In addition to the initial edge populations for the first model run, we also set those grid cells projected to become occupied after a dispersal model run as source points for the subsequent dispersal model run.

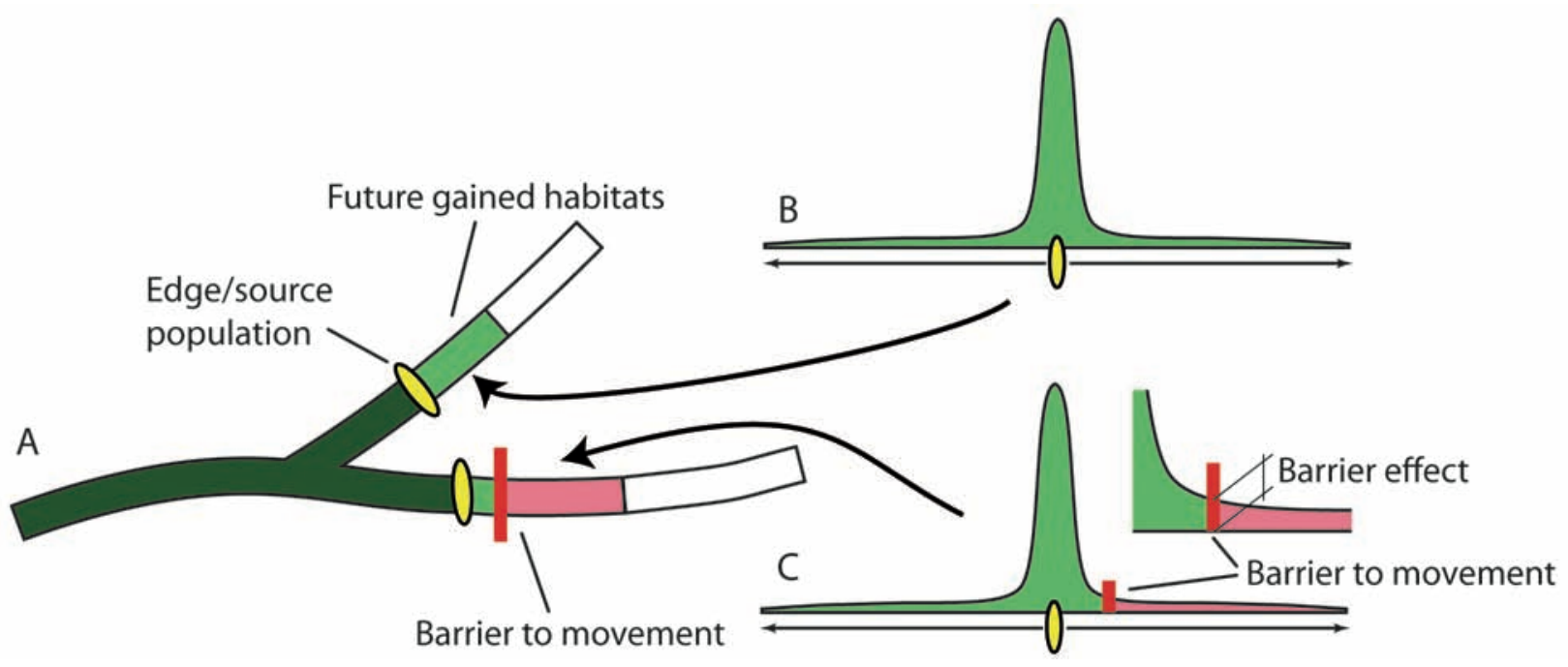


Figure 3. Conceptual model of how species dispersal might compensate for projected future habitat shifts/gains while explicitly accounting for barriers to movement (A). Species dispersal is modeled based on species-specific leptokurtic dispersal kernels and edge populations as source populations (B). Barrier effects reflect the impact of a barrier on dispersal i.e. the height at which the dispersal kernel gets truncated (C).

Barriers are considered in the dispersal model by restricting fish from moving upstream (Radinger et al., 2014), i.e. the dispersal kernel gets truncated at a barrier (Fig. 3). For the modeled River Elbe network, we collated a dataset of 855 barriers (Fig. 1 and Fig. 2) and estimates of their current and planned future passability in upstream direction. Barrier data and basic estimates of barrier passability were made available by the River Basin Community Elbe (FGG Elbe) and the Czech University of Life Sciences in Prague (CULS). We distinguished between three scenarios of longitudinal connectivity: First, we modeled a reference scenario of full longitudinal connectivity $\left(\mathrm{B}_{\mathrm{ref}}\right)$ with all barriers considered as fully passable in both directions. Second, we modeled a present scenario $\left(B_{\text {pres }}\right)$ where all barriers currently assessed as at least partly passable, e.g. with an installed fish pass were considered passable (passability rate $=1, \mathrm{n}=256$ ) and all other barriers were considered impassable (passability rate $=0, \mathrm{n}=599$ ). Thus, $\mathrm{B}_{\text {pres }}$ represents a best-case scenario of current longitudinal connectivity. Third, we modeled a best-case scenario of future longitudinal connectivity $\left(\mathrm{B}_{\text {fut }}\right)$ as targeted in river management plans for the year 2021. Here, all barriers already assessed as (partly) passable or planned to become passable as part of future reconstruction measures (e.g. barrier removal, installation of fish passes $)$ were assigned a passability rate $=1(n=400)$; all barriers considered impassable in 2021 were assigned a passability rate $=0(n=455)$. 
The output of the fish dispersal model for a given species and scenario of longitudinal connectivity is a raster map indicating the dispersal probability of each raster grid cell getting reached after the modeled time frame $(3 \times 5=15$ years $)$.

\subsection{Analysis of barrier effects}

To evaluate barrier effects on species dispersal, we (i) counted the number of species affected by each barrier and (ii) assessed the average impact of each barrier on dispersal across species (i.e. "barrier effect"). Therefore, for all 17 modeled species, we subtracted the raster output map of the dispersal model considering full longitudinal connectivity ( $\left.\mathrm{B}_{\mathrm{ref}}\right)$ from the output map considering currently impassable barriers $\left(\mathrm{B}_{\text {pres }}\right)$. Subsequently, we extracted the difference between both scenario maps for the raster cell directly upstream a barrier as an estimate of the barrier effect on a specific species. Thus, the barrier effect reflects at which height the dispersal kernel gets truncated, which depends on the shape of the species-specific dispersal kernel and the distance between the source population and the barrier (Fig. 3). Calculating the average effect of a barrier across all modeled species allowed us to obtain a single measure of the average impact of a specific barrier on fish dispersal. In addition, we extracted the Strahler stream order (Strahler, 1957) of each barrier from the model river network as a descriptor of its longitudinal position. Here, we refer to $1^{\text {st }}$ order streams as headwater reaches and $\geq 4^{\text {th }}$ order streams as downstream reaches. Spearman rank correlations were used to analyze the relationships (i) between the number of species affected by a barrier and a barrier's longitudinal position and (ii) between the average impact of a barrier on fish dispersal and the longitudinal position.

To assess the impacts of barriers in regard to climate and land use induced habitat shifts, 
we counted the number of cells that (i) are projected newly available habitats for future environmental conditions and (ii) concurrently show a dispersal probability $>0$ for a given scenario of longitudinal connectivity. We determined species-specific dispersal compensation $\mathrm{H}_{\text {dispersal:gain }}$ by calculating the proportion of cells of newly available habitat that can get reached by dispersal for each species (Radinger et al., 2017). Friedman tests combined with Nemenyi post-hoc tests were used to test for differences in $\mathrm{H}_{\text {dispersal:gain }}$ between the three scenarios of longitudinal connectivity.

All spatial analysis were carried out in GRASS GIS (version 7.1svn, GRASS

Development Team, 2012) using its standard functionalities and the r.stream toolset (Jasiewicz and Metz, 2011) for extracting stream order and r.fidimo (Radinger et al., 2014) for modeling fish dispersal. All statistical analysis were conducted in R (version 3.2.5, R Development Core Team, 2016) using the gbm functions from the packages dismo (version 1.0-5, Hijmans et al., 2014) for BRT model building, raster (version 2.3-0, Hijmans, 2014) and rgdal (version 0.9-1, Bivand et al., 2014) for handling spatial data in R, PMCMR (version 4.1, Pohlert, 2014) for calculating Nemenyi post-hoc tests and vioplot (version 0.2, Adler, 2005) for generating violin plots. QGIS (QGIS Development Team, 2009) was used to visualize spatial data and results.

\section{$3 \quad$ Results}

A total of 855 barriers to movement (e.g. weirs, dams) were located in the main network of River Elbe and its major tributaries (Fig. 2). 256 of these barriers have already been assessed as partly or fully passable (e.g. equipped with a fish passage facility) by local river managers. Planned measures of longitudinal continuity in response to the EU-WFD will make another 144 
barriers passable by 2021, leaving 455 barriers still impassable after 2021 . The total number of currently impassable barriers was significantly negatively correlated with stream order (Spearman rank correlation, Spearman $\sigma=-1, \mathrm{p}<0.05$ ), with the highest number in headwater streams $\left(1^{\text {st }}\right.$ order streams; $\left.\mathrm{n}=377\right)$ and lowest number in downstream reaches of the River Elbe network ( $4^{\text {th }}$ order streams; $\left.n=16\right)$. No barriers are located in the most downstream parts of the River Elbe main stem.

Correspondingly, the density of currently impassable barriers was highest in headwater streams ( 0.14 barriers per river kilometer) and significantly decreased downstream (Spearman $\sigma=-1, \mathrm{p}<0.05$ ). The absolute number of barriers planned to be passable by 2021 (i.e. for the $\mathrm{B}_{\text {fut }}$ scenario) significantly decreased downstream (Spearman $\sigma=-1, \mathrm{p}<0.05$ ). In contrast, the relative number of barriers planned to be passable by 2021 compared to the number of currently impassable barriers increased downstream (Spearman $\sigma=1, p<0.1$ ). For example, in the $1^{\text {st }}$ order streams, only $20 \%$ of the barriers will become passable by 2021 , while $69 \%$ of the currently impassable barriers are planned to become passable in $4^{\text {th }}$ order streams.

The fish dispersal model revealed that each of the currently impassable barriers ( $B_{\text {pres }}$ scenario) restricts the movement of two fish species on average (median across 17 modeled species, interquartile range $I Q R=2$, Fig. 4). The median number of species affected by a single barrier was significantly positively related with stream order (Spearman $\sigma=0.26, p<0.001$, Fig. 5) and increased from 1 to 2.75 species in the downstream direction. 


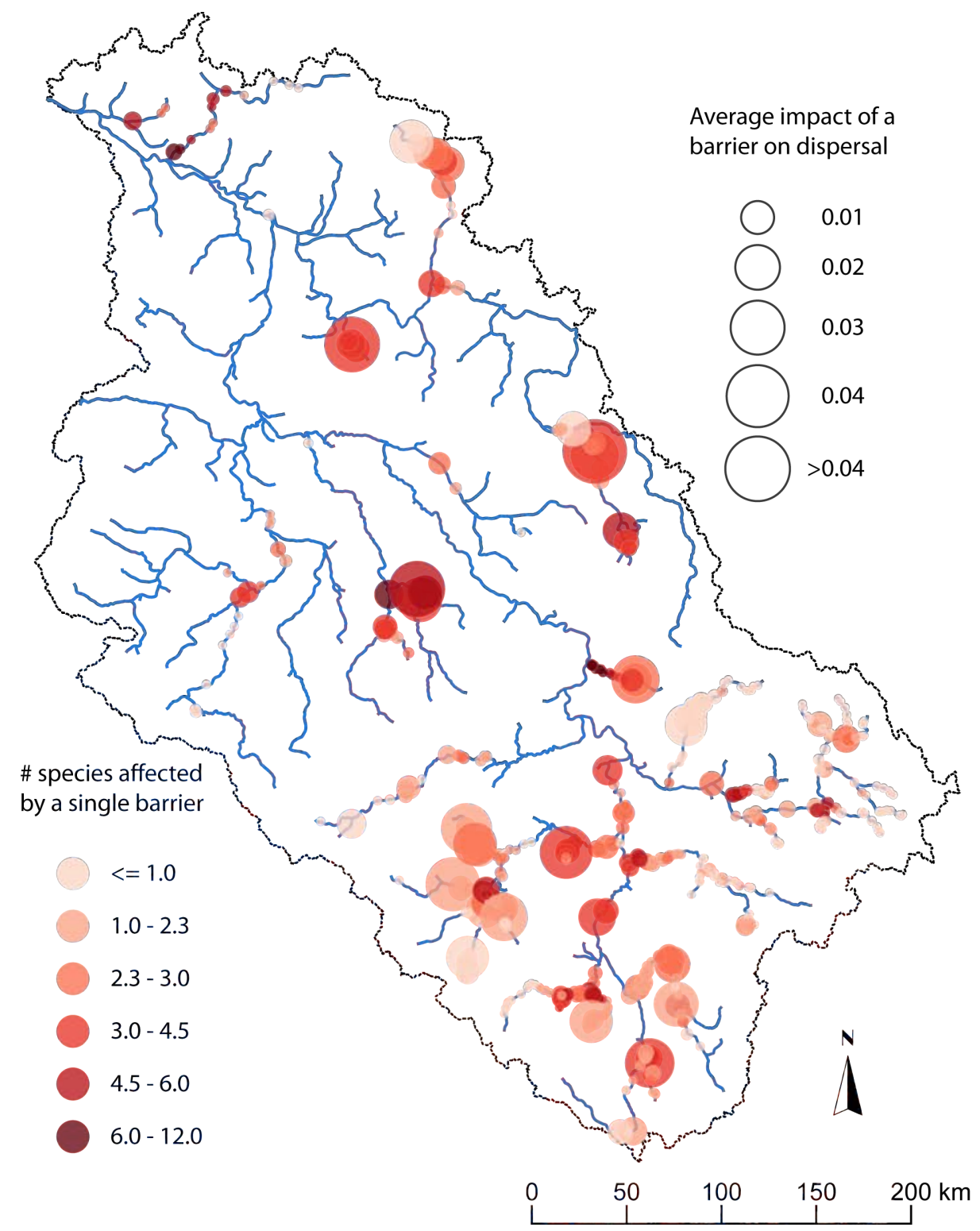

Figure 4. Effects of current barriers on the dispersal of 17 modeled fish species in the River Elbe. Each point refers to a single barrier. Color intensity indicates the number of species affected by a specific barrier (light-dark: 0-12 species). Symbol sizes indicate the average impact of a barrier on the dispersal (i.e. barrier effect) across all affected species as assessed by the dispersal model FIDIMO (i.e. barriers closely related to source populations of many species are larger and darker). 


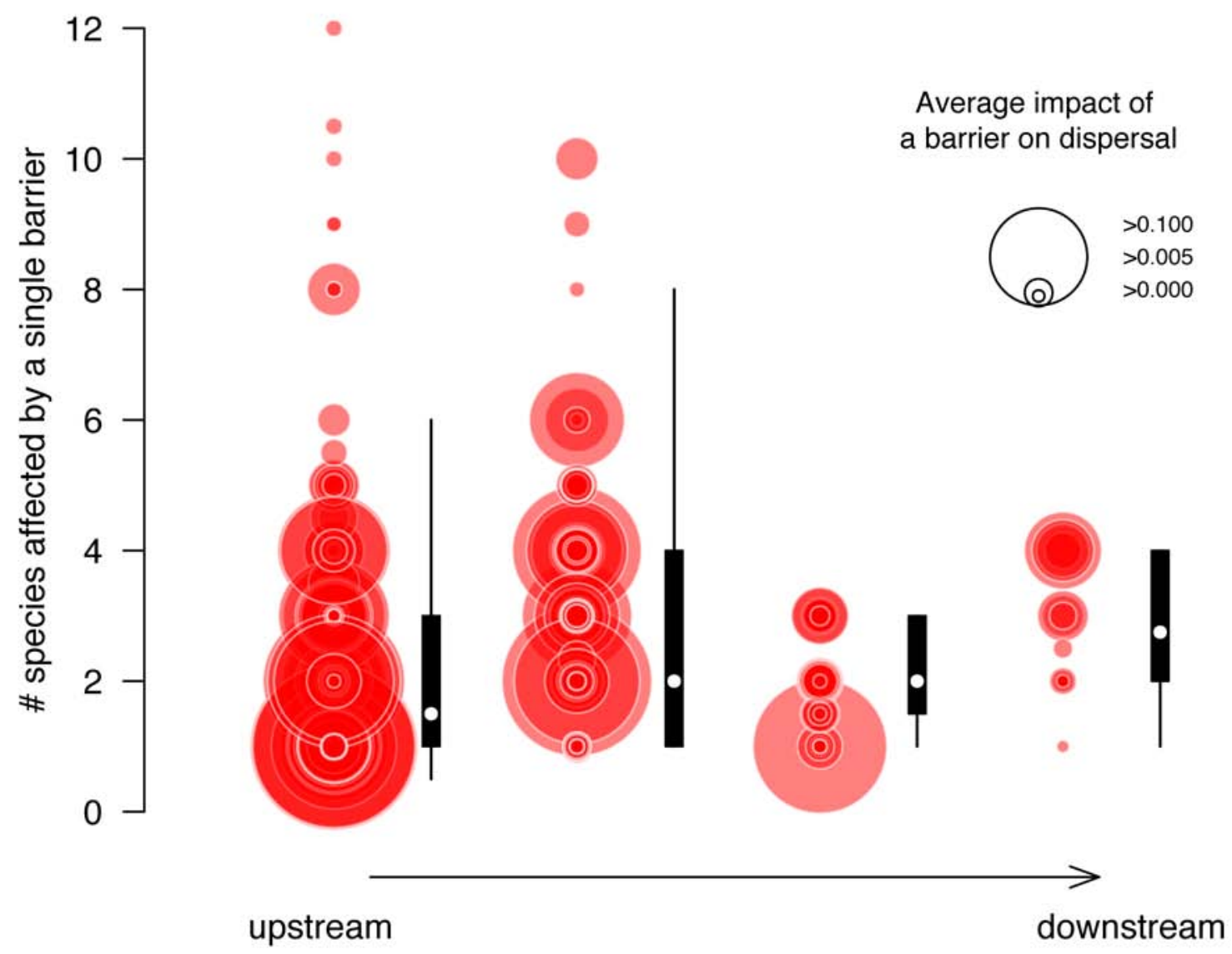

Figure 5. The number of species affected by a single barrier along a longitudinal gradient from upstream (stream order 1) to downstream (stream order 4). Symbol sizes indicate the average impact of a barrier on the dispersal - a metric to which degree barriers truncate the species-specific dispersal kernels - over all affected species at that specific barrier (i.e. larger symbols show larger average impediments of dispersal movements). Bold vertical lines indicate the interquartile range between the first and third quartile, white circles show the median number of species affected. Thin-lined whiskers extend to the last observation within 1.5 times the interquartile range from the quartiles.

The average impact of a barrier on fish dispersal - i.e. "barrier effect" - a metric to which degree barriers truncate the species-specific dispersal kernels - ranged between 0 and 0.33 (median $=0.0003$, Fig. 5). Analogous to the number of species affected by a barrier, the average 
impact of a specific barrier on fish dispersal across species also significantly increased in downstream (Spearman $\sigma=0.29, \mathrm{p}<0.001)$.

In $1^{\text {st }}$ order streams, approximately $65 \%$ of the barriers restricted $\geq 1$ species in the $B_{\text {pres }}$ scenario. This share showed a decreasing, although not significant downstream trend (Spearman $\sigma=-0.8, p=0.33$, Fig. 6 ). The lowest value was observed in $3^{\text {rd }}$ order streams, where only $33 \%$ of the barriers restricted $\geq 1$ species. In contrast, the share of barriers that restricted $\geq 3$ species ranged between $11 \%$ and $29 \%$ and was not correlated with the longitudinal position of a barrier (Spearman $\sigma=0.4, p=0.75$, Fig. 6). Barriers that potentially impeded many species ( $\geq 5$ ) were only located in $1^{\text {st }}$ and $2^{\text {nd }}$ order streams (Fig. 5 and Fig. 6).

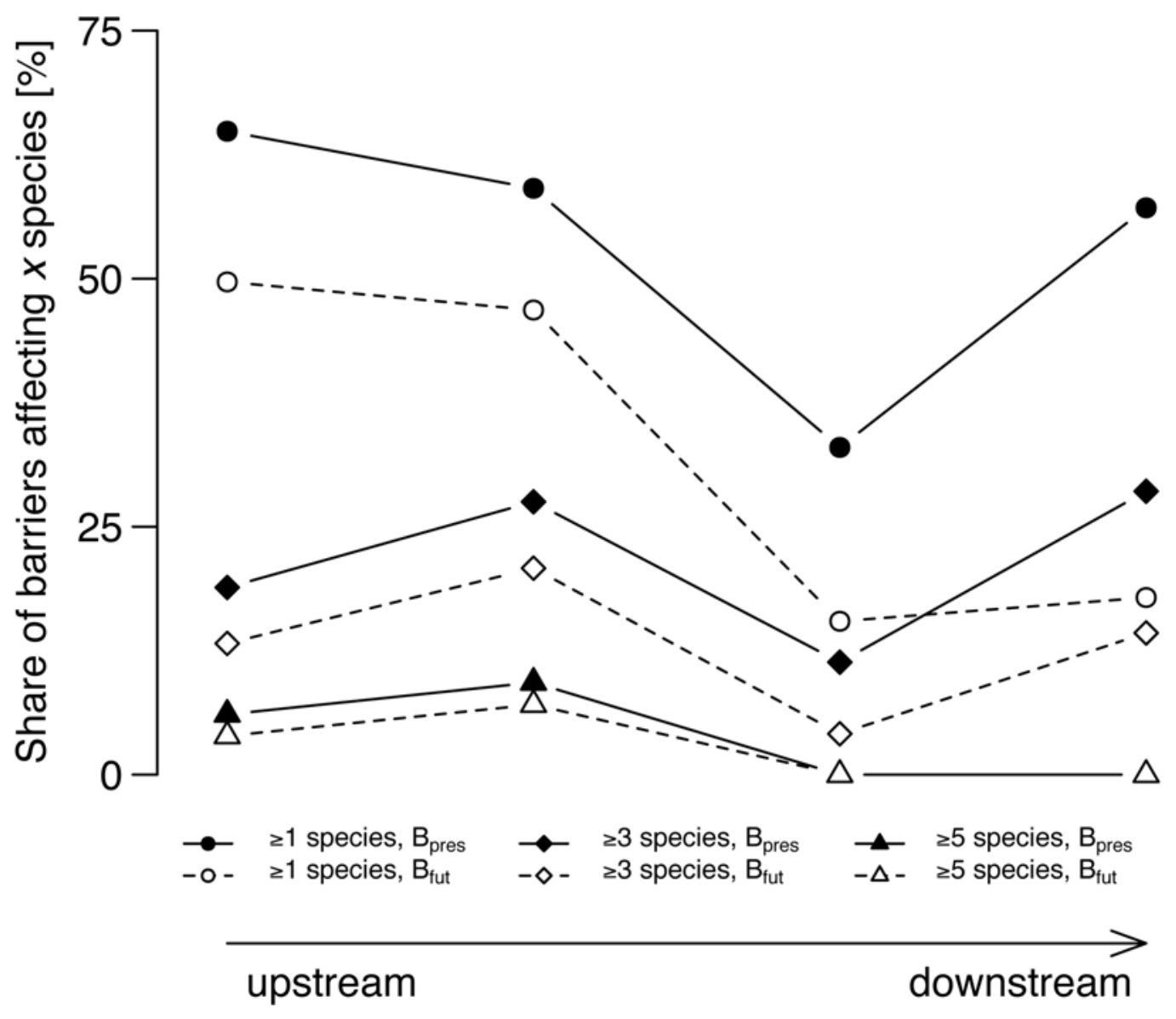

Figure 6. Share of barriers that impede $\geq 1, \geq 3$ and $\geq 5$ species for a given scenario of longitudinal 
connectivity $\left(\mathrm{B}_{\text {pres }}=\right.$ present scenario with 599 impassable barriers, filled symbols; $\mathrm{B}_{\text {fut }}=$ future scenario as planned for 2021, open symbols) along the longitudinal gradient from upstream (stream order 1) to downstream (stream order 4).

For the longitudinal connectivity scenario $B_{\text {fut }}$ (i.e. considering barriers passability as planned for 2021), the share of barriers that impeded the dispersal of species was reduced (Fig. 6). Here, the most dramatic improvements were detected for the downstream reaches of the River Elbe network (e.g. $4^{\text {th }}$ order streams), where the share of barriers that restricted $\geq 1$ species dropped from initially $57 \%$ in the $\mathrm{B}_{\text {pres }}$ scenario to $18 \%$ in the $\mathrm{B}_{\text {fut }}$ scenario.

The predicted habitat gains that can be reached by dispersal $\left(\mathrm{H}_{\text {dispersal:gain }}\right)$ within 15 years varied strongly among the 17 modeled species and between the two scenarios of environmental change, and were particularly affected by the respective scenario of longitudinal connectivity. For a scenario of full longitudinal connectivity $\left(\mathrm{B}_{\mathrm{ref}}\right)$ and moderate environmental change, the median $\mathrm{H}_{\text {dispersal:gain }}$ across all species was $0.50(\mathrm{IQR}=0.52)$, while for the current scenario of longitudinal connectivity $\left(\mathrm{B}_{\text {pres }}\right)$ and severe environmental change, the median $\mathrm{H}_{\text {dispersal:gain was }}$

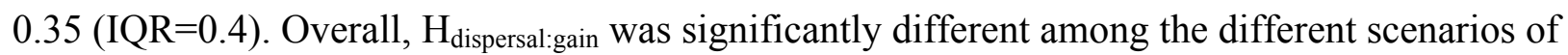
longitudinal connectivity for the moderate (Friedman test, $\chi^{2}=21.81, \mathrm{df}=2, \mathrm{p}<0.001$ ) and the severe future conditions $\left(\chi^{2}=25.48, \mathrm{df}=2, \mathrm{p}<0.001\right)$. In particular, $\mathrm{H}_{\text {dispersal:gain }}$ was significantly different between $\mathrm{B}_{\text {ref }}$ and $\mathrm{B}_{\text {pres }}$ for the moderate (difference in $\mathrm{H}_{\text {dispersal:gain }}=0.030, \mathrm{p}<0.001$, Fig. 7) and severe future conditions (difference in $\mathrm{H}_{\text {dispersal:gain }}=0.034, \mathrm{p}<0.001$ ) and between $\mathrm{B}_{\text {fut }}$ and $\mathrm{B}_{\text {pres }}$ for the severe conditions only (difference in $\mathrm{H}_{\text {dispersal:gain }}=0.014, \mathrm{p}<0.05$ ) as indicated by pairwise Nemenyi post-hoc tests. All other pairwise comparisons of $\mathrm{H}_{\text {dispersal:gain }}$ between the scenarios of longitudinal connectivity were not significant $(\mathrm{p}>0.1)$. 


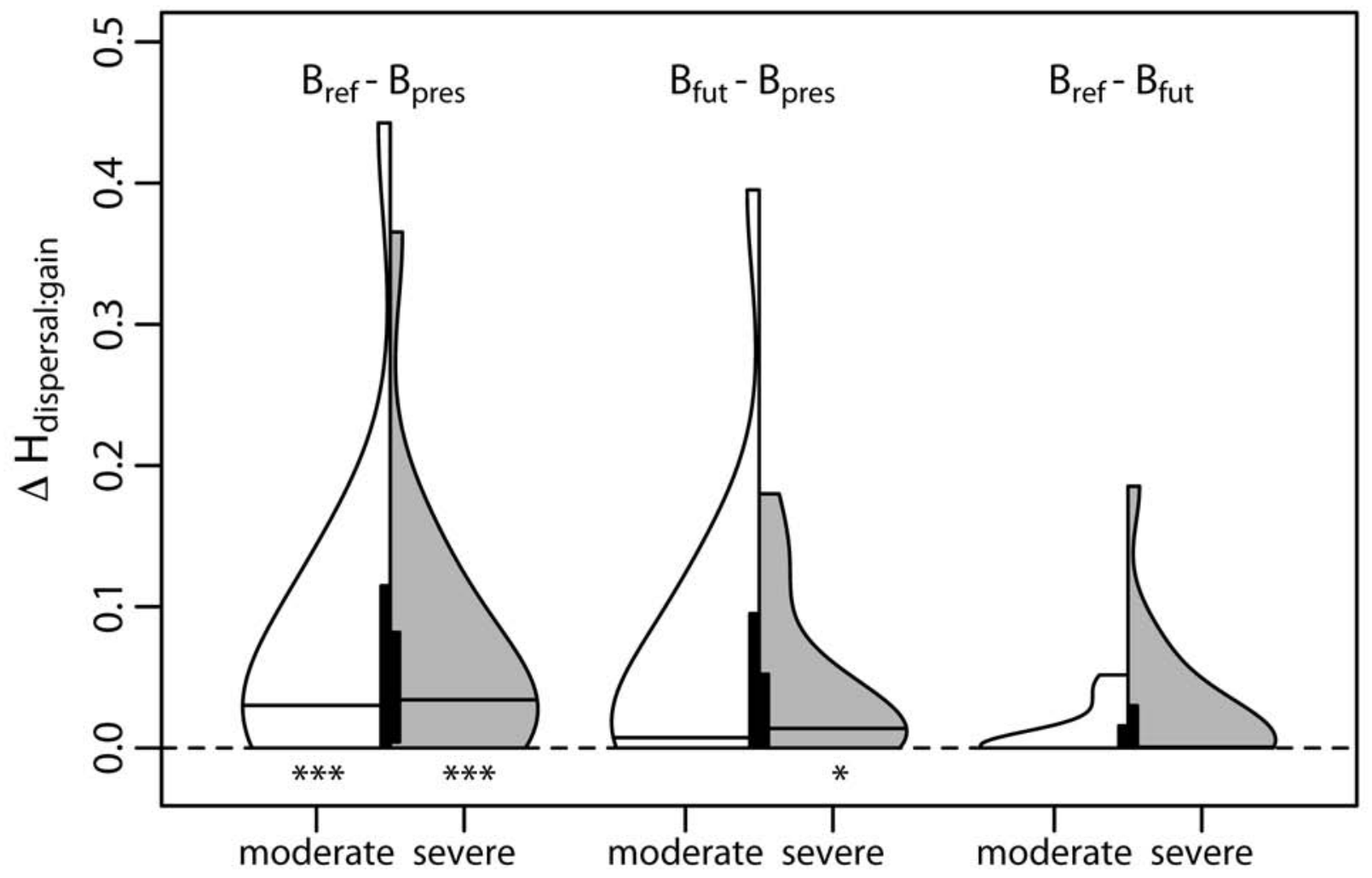

Figure 7. Differences in species-specific dispersal compensation, $\Delta \mathrm{H}_{\text {dispersal:gain, between different }}$ scenarios of longitudinal connectivity: $\mathrm{B}_{\text {ref }}=$ reference scenario of full longitudinal connectivity, $\mathrm{B}_{\text {pres }}=$ present scenario with 599 impassable barriers, $B_{\text {fut }}=$ future scenario as planned for 2021 with 455 impassable barriers. Violin plots show the probability density of $\Delta \mathrm{H}_{\text {dispersal:gain }}$ between two scenarios of longitudinal connectivity for moderate (white) and severe (grey) future environmental conditions, respectively; bold vertical lines indicate the interquartile range between the first and third quartile and horizontal lines show the median. Significance levels $(* \mathrm{p}<0.05 ; * * * \mathrm{p}<0.001)$ are based on Nemenyi post-hoc tests for comparisons of $\mathrm{H}_{\text {dispersal:gain }}$ between the three scenarios of longitudinal connectivity. 


\section{Discussion}

In this study, we assessed the effects of river management related to the restoration of longitudinal connectivity (i.e. barrier passability) on fish species dispersal and evaluated the impacts of barriers on the dispersal of 17 native fish species in the European River Elbe in light of future climate and land use-induced species range shifts.

Our results showed that the current total number and the density of impassable barriers in the River Elbe and its tributaries decrease with stream order, i.e. fewer barriers are located in downstream compared to headwater streams. In particular, the upper and middle River Elbe catchment upstream the confluence of the River Saale (Fig. 2) is considered to have one of the highest densities of barriers (in particular dams) of all European catchments. Presently, about 300 large reservoirs with a total storage volume of over four Billion cubic meters are located in the River Elbe (Simon, 2005). We acknowledge that the condition of a barrier, its position within the river network and the provision of fish protection and migration facilities, rather than the barrier type and its absolute height, determine the effects on river fragmentation. For example, even low-head barriers can substantially influence river fish assemblages (Holcomb et al., 2016), especially barriers with heights or flow velocities exceeding a species' jumping or swimming capacity. Consequently, we did not distinguish between large and small barrier, but considered an estimate of passability for fish of each barrier based on installed fish migration facilities and judgments by experts/river managers. We further admit that the passage efficiency of barriers and fish migration facilities does not only depend on technical properties (e.g., slot width, height difference, flow velocity, attraction flow), but markedly varies with species, life-stage and hydrological/climatological conditions (Bourne et al., 2011; Kemp and O'Hanley, 2010; Prchalová et al., 2011). Unfortunately, the lack of appropriate data did not allow for a more 
differentiated consideration of barrier passability rates here.

Interestingly, the River Elbe main stem does not contain any barrier between the weir Geesthacht (Germany, downstream boundary of the model catchment) and the weir Střekov (Czech Republic) which is the first, though partially passable barrier located more than $600 \mathrm{~km}$ upstream (Prchalová et al., 2011). Therefore, planning to improve longitudinal connectivity focuses primarily on tributaries and lower-order headwater streams. The absolute number of barriers planned to be made passable decreased downstream. This correlates with the manifold higher number of barriers in the headwater sections (compare Fig. 2). However, our results revealed that only about $20 \%$ of the barriers in these upstream reaches will become passable by 2021 , whereas $69 \%$ of the currently impassable barriers will become passable in the downstream reaches of the River Elbe network.

The results of the fish dispersal model revealed that barriers restrict on average the movement of two modeled fish species in the River Elbe network, thereby impeding fishes' capabilities to track future habitat shifts induced by climate and land use change. Moreover, the models indicated that more than one third of the currently impassable barriers in the River Elbe (scenario $\mathrm{B}_{\text {pres }}$ ) are considered to block at least one species. These findings presented here might be considered as conservative estimates, since we only modeled the larger-scale dispersal of 17 (non-migratory) species based on modeled distributions of their occurrence. We did not investigate impacts of barriers on smaller-scale movements or species abundances in close vicinity to a barrier. Similar to our findings, in the eastern Lake Ontario catchments, fish passage models of migratory species indicated that all fish are likely to be blocked by at least one barrier, and that every barrier blocks at least one migratory species (Meixler et al., 2009). In our study, we did not consider diadromous fishes, i.e. species that depend on unrestricted longitudinal 
connectivity between the sea and rivers or vice versa. Accordingly, Wolter (2015) emphasized the particular importance of restoring longitudinal connectivity to the upper headwaters for successful rehabilitation of Atlantic Salmon (Salmo salar), a migratory species in the River Elbe. Moreover, this underlines that improving longitudinal connectivity is indispensable for fish to cope with future environmental change (Radinger et al., 2017). Detailed quantitative assessments of the ecological effects of riverine connectivity are important to manage the impacts of habitat fragmentation and to develop effective conservation measures (Rolls et al., 2013).

Our modeling results further revealed that the average number of species impacted by barriers as well as the average impact of a specific barrier on the dispersal of a single species increases in downstream direction with largest impacts in the most downstream part the of River Elbe catchment. This is in agreement with previous studies showing that main stem dams have larger impacts on connectivity and fish passage than smaller dams within tributaries (e.g. O'Hanley et al., 2013). These findings are explained by typically higher numbers of species in high-order lowland rivers compared to low order streams (e.g. Fieseler and Wolter, 2006; Jungwirth et al., 2003) and by typically larger-bodied and potamodromous species therein showing larger dispersal distances (Radinger and Wolter, 2014). Despite the detected longitudinal gradient of barrier impact, we also note that barriers in headwater streams might constitute large biotic impacts, especially if they restrict the movement of endangered species or affect species interactions (e.g. affiliate species: fish vs. molluscs).

This study goes beyond most previous studies that detected limitations of fishes' abilities to track future climate change (e.g. Comte and Grenouillet, 2013) by explicitly evaluating the restrictions caused by human-induced migration barriers within the river network. This is highly relevant, because our results indicated that the movement of fish species to compensate for 
climate and land use induced habitat shifts $\left(\mathrm{H}_{\text {dispersal:gain }}\right)$ was significantly impacted by existing barriers compared to a scenario of full longitudinal connectivity (Fig. 7), irrespective of the global change scenario considered. Correspondingly, another recent study on climate-induced habitat shifts of river fishes by Gibson-Reinemer et al. (2017) revealed that both natural barriers (i.e. stream slopes) as well as anthropogenic barriers might limit species' abilities to track warming climates. Moreover, managing riverine connectivity is also relevant as the frequency of hydrologic extreme events (e.g. droughts and floods) is projected to increase (IPCC, 2013; Stewart et al., 2015) and the longitudinal stream length between two barriers will have a strong influence on species persistence (Perkin et al., 2015). Correspondingly, investigating the response of butterfly species to climate change, Oliver et al. (2015) showed that a decrease of habitat fragmentations is associated with faster population recovery, in particular after extreme events.

Our results further showed that the improved longitudinal connectivity planned to be achieved by 2021 will allow for fishes' movements to track habitat shifts that do not significantly differ from the full longitudinal connectivity scenario. This finding has major management implications. Firstly, it suggests that the river basin management plan for the River Elbe properly identified and addressed a majority of relevant barriers, at least for the modeled species and in the context of the considered scenarios of future environmental change. Here, the greatest positive effects of planned improvements to connectivity can be expected especially for higher order streams (Fig. 6).

Secondly, it indicates that additional migration facilities beyond the state planned for 2021 might not immediately lead to further improvements of the status of the fish community based on the distributional range and dispersal abilities of the species. This is also because 
connectivity cannot compensate for the habitat losses e.g. due to the barriers' impoundments (higher water depth, lower flow velocities, and increased sedimentation), especially for rheophilic fishes in lowland streams (Birnie-Gauvin et al., 2017). Therefore, we emphasize that restored longitudinal connectivity will not necessarily result in quantifiable biotic improvements, in particular if no new or essential habitats become available for the species, or if connectivity measures are not accompanied by habitat enhancements (Diebel et al., 2010; Radinger and Wolter, 2015). Correspondingly, for the River Elbe catchment, morphological alterations and changes to the flow regime have been identified as one of the major threats contributing that $91 \%$ of the reported river water bodies presently fail to reach the good ecological status or good ecological potential (IKSE, 2015).

Thirdly, to improve the ecological status of river fishes, our results suggest a need for barrier prioritization where it is most important to address first those that cause fragmentations of key habitats for a specific species. Therefore, the presented modeling framework and the applied spatially-explicit fish dispersal model FIDIMO (Radinger et al., 2014) could effectively provide further assistance to identify those barriers that have greatest impact on fish populations and to assess intended river connectivity measures. This is particularly important to river management as rivers provide multiple ecosystem services with partly conflicting interests (e.g. hydropower production, water supply, shipping, recreation, flood control), which requires cost- and resource efficient approaches to prioritize barriers and to reach environmental/ecological targets.

For example, if all specific continuity improvements will be implemented in the River Elbe as planned by 2021, the share of barriers that impede species dispersal will be clearly reduced (Fig. 6). The greatest improvements should be seen in downstream reaches. For the latter, the share of barriers that restrict $\geq 1$ species is projected to drop from currently over $57 \%$ to 
$18 \%$ in the scenario of future longitudinal connectivity. However, depending on the severity of future environmental change the projected shifts of species' habitats might be rather distinct. Consequently, for severe environmental changes, even the planned improvements to river connectivity might not necessarily lead to positive species responses, as species are limited by their own dispersal abilities to track the marked habitat shifts. In particular smaller-bodied, weaker dispersing species are least able to track future environmental change while larger-bodied species are particularly restricted by barriers to movement (Radinger et al., 2017). Accordingly, the dispersal of larger-bodied species (e.g. Silurus glanis) is likely more often restricted by barriers than the dispersal of smaller-bodied species (e.g. Romanogobio belingii, Gymnocephalus cernuus, Barbatula barbatula). However, we also note that network connectivity might foster the spread of invasive species, e.g. as shown for the Great Lakes region (Melles et al., 2015).

In the last decade, several concepts and methods have emerged to provide guidance for improving river continuity and barrier prioritization (Kemp and O'Hanley, 2010; McKay et al., 2016; O’Hanley, 2011; O’Hanley et al., 2013; Segurado et al., 2013). A previous study in three European catchments (including the River Elbe catchment) showed that the density of barriers, the length of non-fragmented river reaches and the spatial distribution of barriers is strongly related to the ecological status of river fishes (Musil et al., 2012). Similarly, we emphasize that successful river management should target for prioritizing concepts for barriers that strongly consider the specific spatial arrangement of barriers in relation to the location of species' populations and suitable habitats.

Although this study focused on the impacts of barriers on fish passage, we acknowledge that barriers have several other impacts on riverine ecosystems and also other biota (macroinvertebrates, plants etc.). These effects are considered to be generally underestimated 
because of time lags and the difficulty to detect a single, simple signal of longitudinal fragmentation that applies to all systems, species and barriers (Fuller et al., 2015). In addition to limited fish passage, barriers modify natural riverine habitats by creating sections of impoundment or residual flow - so-called edge habitats which environmental conditions are influenced by the presence of a barrier (Fuller et al., 2015). As mentioned above, also BirnieGauvin et al. (2017) raised the additional consequences of barriers and emphasized that especially rheophilic fishes in lowland streams are affected by alteration of riverine habitats due to impoundments as this species group depends on fast-flowing water for reproduction and early juvenile development. Moreover, barriers alter the sediment regimes of rivers by increasing water depths and decreasing flow velocity in impounded sections, which leads to increased rates of sedimentation. For example, in the River Elbe catchment, the large number of barriers in combination with an overall deficit of sediments is considered a major cause for the reduced sediment transport (IKSE, 2015), which in turn negatively affects multiple other hydromorphological parameters and leads to the incision of the river channel and a decoupling of the river-floodplain ecosystem (Opperman et al., 2017). Thus, while installing fish migration facilities primarily fosters fish passage, the total removal of barriers could constitute a more holistic management practice to restore longitudinal continuity that also promotes associated hydromorphological processes (e.g. hydromorphological variability, sediment transport). Correspondingly, the number of barrier removals is increasing, though mostly in the U.S. (Stanley and Doyle, 2003). These barrier removals mostly target obsolete and/or smaller obstacles as these commonly contribute relatively little to energy production but might cause disproportionately adverse effects on river ecosystems (Stanley and Doyle, 2003).

In summary, our results have several major implications for river management and the 
restoration of longitudinal connectivity: Firstly, beside their impact on riverine habitats, weirs and dams restrict the movement of riverine fishes and thus their abilities to track future habitat shifts caused by climate and land use change. Secondly, successful improvement of river fish populations requires the prioritization of restoring longitudinal continuity where it is most important to address first those barriers that cause fragmentations of key habitats for a specific species. For the River Elbe, our results suggest that the river basin management plan has most likely identified and addressed the most relevant barriers in respect of the modeled species and the predicted future environmental changes. Thirdly, we emphasize that river management and barrier prioritization must thoroughly consider species-specific movement and dispersal abilities as well as the specific spatial arrangement of barriers in relation to the spatial distribution of species' populations and suitable habitats within a river system. For further improvements of the distribution or status of the fish assemblage, efforts in improving longitudinal connectivity need to be accompanied by significant improvements of species habitats. 


\section{Acknowledgements}

This study is part of the BiodivERsA project "FISHCON" and has been funded by the German Federal Ministry for Education and Research (grant number 01LC1205). We are very grateful to N. Dendoncker who provided data and maps of future land use scenarios and to the River Basin Community Elbe (FGG Elbe), the Czech University of Life Sciences in Prague (CULS), the Institute of Inland Fisheries in Potsdam-Sacrow (IFB), the Leibniz-Institute of Freshwater Ecology and Inland Fisheries in Berlin (IGB) who kindly provided fish data. Barrier

data were kindly provided by the FGG Elbe and CULS Prague. We thank B. Goeller for English language editing of the manuscript and three anonymous reviewers for their constructive comments on the manuscript.

\section{Supplementary material}

Table S1. Predictor variables $(n=36)$ used in the boosted regression tree models comprising of 19 bioclimatic variables, 12 land use variables and 5 stream topological variables. 


\section{References}

Adler, D., 2005. vioplot: Violin plot. http://cran.r-project.org/package=vioplot. (accessed 27.08.2017)

Birnie-Gauvin, K., Aarestrup, K., Riis, T.M.O., Jepsen, N., Koed, A., 2017. Shining a light on the loss of rheophilic fish habitat in lowland rivers as a forgotten consequence of barriers, and its implications for management. Aquat. Conserv. Mar. Freshw. Ecosyst. 1-5.

Bivand, R., Keitt, T., Rowlingson, B., 2014. rgdal: Bindings for the Geospatial Data Abstraction Library. http://cran.r-project.org/package=rgdal. (accessed 27.08.2017)

Bourne, C.M., Kehler, D.G., Wiersma, Y.F., Cote, D., 2011. Barriers to fish passage and barriers to fish passage assessments: the impact of assessment methods and assumptions on barrier identification and quantification of watershed connectivity. Aquat. Ecol. 45, 389-403.

Brevé, N.W.P.P., Buijse, A.D., Kroes, M.J., Wanningen, H., Vriese, F.T., 2014. Supporting decision-making for improving longitudinal connectivity for diadromous and potamodromous fishes in complex catchments. Sci. Total Environ. 496, 206-218.

Comte, L., Grenouillet, G., 2013. Do stream fish track climate change? Assessing distribution shifts in recent decades. Ecography (Cop.). 36, 1236-1246.

Cote, D., Kehler, D.G., Bourne, C., Wiersma, Y.F., 2009. A new measure of longitudinal connectivity for stream networks. Landsc. Ecol. 24, 101-113.

Dendoncker, N., Bogaert, P., Rounsevell, M., 2006. A statistical method to downscale aggregated land use data and scenarios. J. Land Use Sci. 1, 63-82.

Dendoncker, N., Rounsevell, M., Bogaert, P., 2007. Spatial analysis and modelling of land use distributions in Belgium. Comput. Environ. Urban Syst. 31, 188-205.

Diebel, M.W.W., Maxted, J.T.T., Jensen, O.P.P., Vander Zanden, M.J.J., 2010. A spatial 
autocorrelative model for targeting stream restoration to benefit sensitive nongame fishes. Can. J. Fish. Aquat. Sci. 67, 165-176.

Elith, J., Leathwick, J., 2013. Boosted Regression Trees for ecological modeling. CRAN vignette 1-22. https://cran.r-project.org/web/packages/dismo/vignettes/brt.pdf (accessed 27.08.2017) European Parliament and Council of the European Union, 2000. Directive 2000/60/EC of the European Parliament and of the Council of 23 October 2000 establishing a framework for Community action in the field of water policy. Off. J. Eur. Communities 1-72.

Fieseler, C., Wolter, C., 2006. A fish-based typology of small temperate rivers in the northeastern lowlands of Germany. Limnologica 36, 2-16.

Froese, R., Pauly, D., 2016. FishBase http://www.fishbase.org (accessed 11.08.2017)

Fuller, M.R., Doyle, M.W., Strayer, D.L., 2015. Causes and consequences of habitat fragmentation in river networks. Ann. N. Y. Acad. Sci. 1355, 31-51.

Gibson-Reinemer, D.K., Rahel, F.J., Albeke, S.E., Fitzpatrick, R.M., 2017. Natural and anthropogenic barriers to climate tracking in river fishes along a mountain-plains transition zone. Divers. Distrib. 23, 761-770.

Giorgetta, M.A., Jungclaus, J., Reick, C.H., Legutke, S., Bader, J., Böttinger, M., Brovkin, V., Crueger, T., Esch, M., Fieg, K., Glushak, K., Gayler, V., Haak, H., Hollweg, H.-D., Ilyina, T., Kinne, S., Kornblueh, L., Matei, D., Mauritsen, T., Mikolajewicz, U., Mueller, W., Notz, D., Pithan, F., Raddatz, T., Rast, S., Redler, R., Roeckner, E., Schmidt, H., Schnur, R., Segschneider, J., Six, K.D., Stockhause, M., Timmreck, C., Wegner, J., Widmann, H., Wieners, K.-H., Claussen, M., Marotzke, J., Stevens, B., 2013. Climate and carbon cycle changes from 1850 to 2100 in MPI-ESM simulations for the Coupled Model Intercomparison Project phase 5. J. Adv. Model. Earth Syst. 5, 572-597. 
Gouskov, A., Reyes, M., Wirthner-Bitterlin, L., Vorburger, C., 2016. Fish population genetic structure shaped by hydroelectric power plants in the upper Rhine catchment. Evol. Appl. 9, 394-408.

Graf, W.L., 2006. Downstream hydrologic and geomorphic effects of large dams on American rivers. Geomorphology 79, 336-360.

GRASS Development Team, 2012. Geographic Resources Analysis Support System (GRASS) Software, Version 7.0. Open Source Geospatial Foundation. http://grass.osgeo.org.

Hijmans, R.J., 2014. raster: Geographic analysis and modeling. http://cran.rproject.org/package=raster. (accessed 27.08.2017)

Hijmans, R.J., Phillips, S., Leathwick, J., Elith, J., 2014. dismo: Species distribution modeling. http://cran.r-project.org/package=dismo. $($ accessed 27.08.2017)

Holcomb, J.M., Nichols, R.B., Gangloff, M.M., 2016. Effects of small dam condition and drainage on stream fish community structure. Ecol. Freshw. Fish 25, 553-564.

IKSE, 2015. Internationaler Bewirtschaftungsplan für die Flussgebietseinheit Elbe für den Zeitraum 2016-2021 - Teil A. Internationale Kommission zum Schutz der Elbe (IKSE), Magdeburg.

IPCC, 2013. Summary for Policymakers, in: Stocker, T.., Qin, D., Plattner, G.-K., Tignor, M., Allen, S.K., Boschung, J., Nauels, A., Xia, Y., Bex, V., Midgley, P.M. (Eds.), Climate Change 2013: The Physical Science Basis. Contribution of Working Group I to the Fifth Assessment Report of the Intergovernmental Panel on Climate Change. Cambridge University Press, Cambridge, pp. 3-30.

Jasiewicz, J., Metz, M., 2011. A new GRASS GIS toolkit for Hortonian analysis of drainage networks. Comput. Geosci. 37, 1162-1173. 
Jungwirth, M., Haidvogl, G., Moog, O., Muhar, S., Schmutz, S., 2003. Angewandte

Fischökologie an Fließgewässern. Facultas Universitätsverlag, Vienna, Austria.

Kail, J., Guse, B., Radinger, J., Schröder, M., Kiesel, J., Kleinhans, M., Schuurman, F., Fohrer, N., Hering, D., Wolter, C., 2015. A Modelling Framework to Assess the Effect of Pressures on River Abiotic Habitat Conditions and Biota. PLoS One 10, e0130228.

Kemp, P.S., O’Hanley, J.R., 2010. Procedures for evaluating and prioritising the removal of fish passage barriers: a synthesis. Fish. Manag. Ecol. 17, 297-322.

Kuemmerlen, M., Stoll, S., Haase, P., 2016. How barriers shape freshwater fish distributions: a species distribution model approach. PeerJ Prepr. 1-42. DOI: 10.7287/peerj.preprints.2112v2.

Kühn, I., Pompe, S., Trautmann, S., Böhning-Gaese, K., Essl, F., Rabitsch, W., 2013. Klimawandeleffekte morgen: Was könnte noch kommen?, in: Essl, F., Rabitsch, W. (Eds.), Biodiversität Und Klimawandel. Springer, Heidelberg, Berlin, pp. 86-159.

Ligon, F.K., Dietrich, W.E., Trush, W.J., 1995. Downstream Ecological Effects of Dams. Bioscience 45, 183-192.

Liu, C., Berry, P.M., Dawson, T.P., Pearson, R.G., 2005. Selecting thresholds of occurrence in the prediction of species distributions. Ecography (Cop.). 28, 385-393.

Marmion, M., Parviainen, M., Luoto, M., Heikkinen, R.K., Thuiller, W., 2009. Evaluation of consensus methods in predictive species distribution modelling. Divers. Distrib. 15, 59-69.

Marschall, E.A., Mather, M.E., Parrish, D.L., Allison, G.W., McMenemy, J.R., 2011. Migration delays caused by anthropogenic barriers: modeling dams, temperature, and success of migrating salmon smolts. Ecol. Appl. 21, 3014-3031.

McKay, S.K., Cooper, A.R., Diebel, M.W., Elkins, D., Oldford, G., Roghair, C., Wieferich, D., 
2016. Informing Watershed Connectivity Barrier Prioritization Decisions: A Synthesis. River Res. Appl. 33, 847-862.

Meixler, M.S., Bain, M.B., Todd Walter, M., 2009. Predicting barrier passage and habitat suitability for migratory fish species. Ecol. Modell. 220, 2782-2791.

Melles, S.J., Chu, C., Alofs, K.M., Jackson, D.A., 2015. Potential spread of Great Lakes fishes given climate change and proposed dams: an approach using circuit theory to evaluate invasion risk. Landsc. Ecol. 30, 919-935.

Meyer, J.L., Sale, M.J., Muiholland, P.J., Poff, N.L., 1999. Impacts of climate change on aquatic ecosystems functioning and health. J. Am. Water Resour. Assoc. 35, 1373-1386.

Moss, R.H., Edmonds, J.A., Hibbard, K.A., Manning, M.R., Rose, S.K., van Vuuren, D.P., Carter, T.R., Emori, S., Kainuma, M., Kram, T., Meehl, G.A., Mitchell, J.F.B., Nakicenovic, N., Riahi, K., Smith, S.J., Stouffer, R.J., Thomson, A.M., Weyant, J.P., Wilbanks, T.J., 2010. The next generation of scenarios for climate change research and assessment. Nature $463,747-756$.

Musil, J., Horký, P., Slavík, O., Zbořil, A., Horká, P., 2012. The response of the young of the year fish to river obstacles: Functional and numerical linkages between dams, weirs, fish habitat guilds and biotic integrity across large spatial scale. Ecol. Indic. 23, 634-640.

O'Hanley, J.R., 2011. Open rivers: Barrier removal planning and the restoration of free-flowing rivers. J. Environ. Manage. 92, 3112-3120.

O’Hanley, J.R., Wright, J., Diebel, M., Fedora, M.A., Soucy, C.L., 2013. Restoring stream habitat connectivity: A proposed method for prioritizing the removal of resident fish passage barriers. J. Environ. Manage. 125, 19-27.

Oliver, T.H., Marshall, H.H., Morecroft, M.D., Brereton, T., Prudhomme, C., Huntingford, C., 
2015. Interacting effects of climate change and habitat fragmentation on drought-sensitive butterflies. Nat. Clim. Chang. 5, 941-945.

Opperman, J.J., Moyle, P.B., Larsen, E.W., Florsheim, J.L., Manfree, A.D., 2017. Floodplains: processes and management for ecosystem services. University of California Press, Oakland, CA, USA.

Perkin, J.S., Gido, K.B., Cooper, A.R., Turner, T.F., Osborne, M.J., Johnson, E.R., Mayes, K.B., 2015. Fragmentation and dewatering transform Great Plains stream fish communities. Ecol. Monogr. 85, 73-92.

Petts, G.E., Gurnell, A.M., 2005. Dams and geomorphology: Research progress and future directions. Geomorphology 71, 27-47.

Pohlert, T., 2014. The Pairwise Multiple Comparison of Mean Ranks Package (PMCMR). http://cran.r-project.org/package=PMCMR. (accessed 27.08.2017)

Prchalová, M., Horký, P., Slavík, O., Vetešník, L., Halačka, K., 2011. Fish occurrence in the fishpass on the lowland section of the River Elbe, Czech Republic, with respect to water temperature, water flow and fish size. Folia Zool. 60, 104-114.

QGIS Development Team, 2009. QGIS Geographic Information System.

R Development Core Team, 2016. R: A Language and Environment for Statistical Computing. R Foundation for Statistical Computing, http://www.r-project.org/, Vienna, Austria.

Radinger, J., Essl, F., Hölker, F., Horký, P., Slavík, O., Wolter, C., 2017. The future distribution of river fish: The complex interplay of climate and land use changes, species dispersal and movement barriers. Glob. Chang. Biol. 1-17. DOI: 10.1111/gcb.13760.

Radinger, J., Hölker, F., Horký, P., Slavík, O., Dendoncker, N., Wolter, C., 2016. Synergistic and antagonistic interactions of future land use and climate change on river fish 
assemblages. Glob. Chang. Biol. 22, 1505-1522.

Radinger, J., Kail, J., Wolter, C., 2014. FIDIMO - A Free and Open Source GIS based dispersal model for riverine fish. Ecol. Inform. 24, 238-247.

Radinger, J., Wolter, C., 2014. Patterns and predictors of fish dispersal in rivers. Fish Fish. 15, 456-473.

Radinger, J., Wolter, C., 2015. Disentangling the effects of habitat suitability, dispersal, and fragmentation on the distribution of river fishes. Ecol. Appl. 25, 914-927.

Reyjol, Y., Argillier, C., Bonne, W., Borja, A., Buijse, A.D., Cardoso, A.C., Daufresne, M., Kernan, M., Ferreira, M.T., Poikane, S., Prat, N., Solheim, A.-L., Stroffek, S., UsseglioPolatera, P., Villeneuve, B., van de Bund, W., 2014. Assessing the ecological status in the context of the European Water Framework Directive: Where do we go now? Sci. Total Environ. 497-498, 332-344.

Rolls, R.J., Ellison, T., Faggotter, S., Roberts, D.T., 2013. Consequences of connectivity alteration on riverine fish assemblages: potential opportunities to overcome constraints in applying conventional monitoring designs. Aquat. Conserv. Mar. Freshw. Ecosyst. 23, 624640.

Segurado, P., Branco, P., Ferreira, M.T., 2013. Prioritizing restoration of structural connectivity in rivers: a graph based approach. Landsc. Ecol. 28, 1231-1238.

Simon, M., 2005. Die Elbe und ihr Einzugsgebiet: ein geographisch-hydrologischer und wasserwirtschaftlicher Überblick. Internationale Kommission zum Schutz der Elbe (IKSE), Magdeburg.

Spangenberg, J.H., Bondeau, A., Carter, T.R., Fronzek, S., Jaeger, J., Jylhä, K., Kühn, I., Omann, I., Paul, A., Reginster, I., Rounsevell, M., Schweiger, O., Stocker, A., Sykes, M.T., Settele, 
J., 2012. Scenarios for investigating risks to biodiversity. Glob. Ecol. Biogeogr. 21, 5-18.

Stanley, E.H., Doyle, M.W., 2003. Trading off: the ecological effects of dam removal. Front. Ecol. Environ. 1, 15-22.

Stewart, I.T., Ficklin, D.L., Carrillo, C.A., McIntosh, R., 2015. 21st century increases in the likelihood of extreme hydrologic conditions for the mountainous basins of the Southwestern United States. J. Hydrol. 529, 340-353.

Strahler, A.N., 1957. Quantitative Analysis of Watershed Geomorphology. Trans. Am. Geophys. Union 38, 913-920.

Wolter, C., 2015. Historic catches, abundance, and decline of Atlantic salmon Salmo salar in the River Elbe. Aquat. Sci. 77, 367-380.

Woodward, G., Perkins, D.M., Brown, L.E., 2010. Climate change and freshwater ecosystems: impacts across multiple levels of organization. Philos. Trans. R. Soc. B 365, 2093-2106. 


\section{Tables}

Table 1. The 17 modeled fish species in the River Elbe network. L is the common speciesspecific body length (Froese and Pauly, 2016) as used in the fish dispersal model.

\begin{tabular}{lllc}
\hline Species Name & Scientific Name & Family & L [mm] \\
\hline Common bream & Abramis brama & Cyprindae & 250 \\
Bleak & Alburnus alburnus & Cyprindae & 150 \\
Asp & Aspius aspius & Cyprindae & 550 \\
Stone loach & Barbatula barbatula & Nemacheilidae & 120 \\
White bream & Blicca bjoerkna & Cyprindae & 200 \\
Bullhead & Cottus gobio & Cottidae & 100 \\
Northern pike & Esox lucius & Esocidae & 400 \\
Ruffe & Gymnocephalus cernuus & Percidae & 120 \\
Ide & Leuciscus idus & Cyprindae & 300 \\
Burbot & Lota lota & Lotidae & 400 \\
European perch & Perca fluviatilis & Percidae & 250 \\
River gudgeon & Romanogobio belingii & Cyprindae & 100 \\
Roach & Rutilus rutilus & Cyprindae & 250 \\
Brown trout & Salmo trutta fario & Salmonidae & 200 \\
Pikeperch & Sander lucioperca & Percidae & 500 \\
European catfish & Silurus glanis & Siluridae & 1500 \\
Chub & Squalius cephalus & Cyprindae & 300 \\
\hline & & & \\
\hline
\end{tabular}


Table 2. The number of passable, impassable and planned passable barriers in the modeled River Elbe network across Strahler stream order.

\begin{tabular}{lccccc}
\hline Stream order & $\mathbf{1}$ & $\mathbf{2}$ & $\mathbf{3}$ & $\mathbf{4}$ & $\mathbf{5}$ \\
\hline Currently passable & 84 & 101 & 59 & 12 & 0 \\
Planned passable by 2021 & 74 & 38 & 21 & 11 & 0 \\
Impassable by 2021 & 303 & 130 & 17 & 5 & 0 \\
\hline
\end{tabular}

